\title{
ANALISIS KINERJA DENGAN PENDEKATAN RASIO CAMEL
}

\section{Sri Murdiati ${ }^{\bowtie}$, Medi Tri Purwanto}

Universitas Pancasakti Tegal, Tegal dan STIE Widya Manggalia, Brebes, Indonesia

\section{Info Artike}

\section{Sejarah Artikel:}

Diterima Desember 2013

Disetujui Januari 2014

Dipublikasikan Maret 2014

\section{Keywords:}

Camel;

Healthiness of Bank;

Capital;

Assets Earnings;

Liquidity.

\begin{abstract}
Abstrak
Tujuan penelitian ini adalah untuk menganalisis tingkat kesehatan bank dilihat dari kategori CAMEL. Metode penelitian yang digunakan adalah studi kasus di PD BPR BKK Banjarharjo. Dalam menguji hipotesis digunakan alat analisis CAMEL. Hasil penelitian ini yaitu modal pada 2008 sampai 2010 termasuk dalam kriteria sehat. ROA meningkat 2008 sampai 2010 dengan kriteria sehat bagi biaya operasional yang dikeluarkan oleh pendapatan operasional yang seimbang. Rasio Kas tahun 2008 sampai 2010 termasuk dalam kriteria sehat berarti bank memiliki kemampuan untuk mengelola asset yang digunakan untuk membayar kewajiban. LDR mengalami tren yang signifikan selama tahun 2008 sampai 2010 sehingga dana yang diterima bank untuk meningkatkan baik tabungan, deposito berjangka, modal inti, yang berarti kemampuan bank untuk meningkatkan penyaluran kredit, IRR menunjukan nilai positif dalam menghadapi resiko pasar. Pengembangan tingkat kesehatan pada tahun 2008 sampai 2010 untuk komponen Capital, Assets, Laba dan Likuiditas meningkat.
\end{abstract}

\section{PERFORMANCE ANALYSIS USING BY CAMEL RATIO}

\begin{abstract}
The goal of this research is to analyze the healtiness of banks seen from CAMEL category. The research applied a case study in PD BPR BKK Banjarharjo. The hypotheses tested using CAMEL analysis tools. The result of the study is that the modal used 2008 until 2010 is consideredin a healthy criteria. The increasing ROA in 2008 until 2010 is considered healthy criteria for operational expenses incurred by the operating income. Such condition meant that the banks are able to manage the assets which are used to pay the obligations. The significant increasing of LDR over the years 2008 until 2010 makes the received funds by the bank to increase the savings deposits, time deposits and the core capital. As the recunts, the banks are able to increase credit disstribution. More over, the IRR showed a positive values in the face of market risks and the development of healthy levels in 2008 until 2010 for the components of Capital, Assets, Earnings and Liquidity tends to increase.
\end{abstract}

JEL Classification: G2, G21 
Sri Murdiati \& Medi Tri Purwanto / Analisis Kinerja dengan Pendekatan ...

\section{PENDAHULUAN}

Peraturan Bank Indonesia No. 6/10/ PBI/2004 tanggal 12 April 2004 tentang Sistem Penilaian Tingkat Kesehatan BPR menjelaskan bahwa bank wajib melakukan penilaian tingkat kesehatan bank secara triwulan. Peraturan tersebut menjelaskan bahwa tingkat kesehatan bank merupakan hasil penilaian kualitatif atas berbagai aspek yang berpengaruh terhadap kondisi atau kinerja suatu bank melalui penilaian faktor permodalan, kualitas asset, manajemen, rentabilitas,likuiditas, dan sensitivitas terhadap risiko pasar. Penilaian terhadap faktor-faktor tersebut dilakukan melalui penilaian kuantitatif dan atau kualitatif setelah mempertimbangkan unsur judgement yang didasarkan atas materialitas dan signifikansi dari faktor-faktor penilaian serta pengaruh dari faktor lainnya seperti kondisi industri perbankan dan perekonomian nasional.

Penilaian faktor-faktor komponen dilakukan dengan sistem kredit (system reward) yang dinyatakan dalam nilai kredit 0 sampai 100 . Hasil kuantifikatif dari komponen-komponen tersebut dinilai lebih lanjut dengan memperhatikan informasi dan aspek-aspek lain yang secara material berpengaruh terhadap kondisi dan perkembangan masing-masing faktor. Tingkat kesehatan bank digolongkan dalam empat kategori yaitu: sehat, cukup sehat, kurang sehat dan tidak sehat.

Sebagai pengawas bank, Bank Indonesia juga menilai performance bank dengan memperhatikan enam indikator yang disebut CAMEL. Penilaian sistem CAMEL ini, mengukur apakah manajemen bank telah melaksanakan sistem perbankan dengan asas-asas yang sehat.Indikator yang dapat mempengaruhi Camel yaitu aspek permodalan (Capital).Penilaian pendekatan kuantitatif dan kualitatif faktor permodalan antara lain dilakukan melalui penilaian terhadap komponen-komponen: kecukupan pemenuhan Kewajiban Penyediaan Modal Minimum (KPMM) terhadap ketentuan yang berlaku, komposisi permodalan, trend ke depan/proyeksi KPMM, aktiva produktif yang diklasifikasikan dibandingkan dengan modal bank, kemampuan bank memelihara kebutuhan penambahan modal yang berasal dari keuntungan (laba ditahan), rencana permodalan bank untuk mendukung pertumbuhan usaha, akses kepada sumber permodalan, serta kinerja keuangan pemegang saham untuk meningkatkan permodalan bank ( Zhang, et al., 2008; Shehzad et al., 2010; Arnold et al., 2012; Shaw et al., 2013).

Penilaian pendekatan kuantitatif dan kualitatif faktor kualitas asset antara lain dilakukan melalui penilaian terhadap komponen-komponen yaitu aktiva produktif yang diklasifikasikan dibandingkan dengan total aktiva produktif, debitur inti kredit diluar pihak terkait dibandingkan dengan total kredit, perkembangan aktiva produktif bermasalah non performing assets dibandingkan dengan aktiva produktif, tingkat kecukupan pembentukan Penyisihan Penghapusan Aktiva Produktif (PPAP), kecukupan kebijakan dan prosedur aktiva produktif, sistem kaji ulang (review) internal terhadap aktiva produktif, dokumen aktiva produktif, kinerja penanganan aktiva produktif bermasalah.Penilaian terhadap faktor manajemen antara lain dilakukan melalui penilaian terhadap komponenkomponen yaitu manajemen umum, penerapan sistem manajemen risiko, kepatuhan bank terhadap ketentuan yang berlaku serta komitmen kepada Bank Indonesia dan atau pihak lain.

Penilaian pendekatan kuantitatif dan kualitatif faktor rentabilitas antara lain dilakukan melalui penilaian terhadap komponen-komponen yaitu Return On Assets (ROA),Return On Equity (ROE),Net Interest Margin (NIM), biaya Operasional dibandingkan dengan Pendapatan Operasional (BOPO), perkembangan laba operasional, komposisi portofolio aktiva produktif dan diversifikasi pendapatan, penerapan prinsip akuntansi dalam pengakuan pendapatan dan biaya, prospek laba operasional (Pilloff \& Rhoades, 2002; Gunsel, 2007). Penilaian pendekatan kuantitatif dan kualitatif faktor likuiditas antara lain dilakukan melalui penilaian terhadap komponen-komponen yaitu aktiva likuid kurang dari satu bulan dibandingkan dengan pasiva likuid kurang dari satu bulan, 1-month matu- 
rity mismatch ratio, Loan to Deposit Ratio (LDR), proyeksi cash flow tiga bulan mendatang, ketergantungan pada dana antara bank dan deposan inti, kebijakan dan pengelolaan likuiditas (Assets and Liabilities Management/ ALMA), kemampuan bank untuk memperoleh akses kepada pasar uang, pasar modal, atau sumber-sumber pendanaan lainnya, stabilitas Dana Pihak Ketiga (DPK) (Hays et al. 2009).

Penilaian pendekatan kuantitatif dan kualitatif faktor sensitivitas terhadap resiko pasar antara lain dilakukan melalui penilaian terhadap komponen-komponen yaitu modal atau cadangan yang dibentuk untuk mengatasifluktuasi suku bunga dibandingkan dengan potential loss sebagai akibat fluktuasi (adverse movement) suku bunga, modal atau cadangan yang dibentuk untuk mengatasifluktuasi nilai tukar dibandingkan dengan potential loss sebagai akibat fluktuasi (adverse movement) nilai tukar, kecukupan penerapan sistem manajemen risiko pasar.

Sesuai SK DIR BI No. 30/12/KEP/DIR dan SE BI No.30/3/UPPB tanggal 30 April 1997 tentang tata cara penilaian tingkat kesehatan BPR, faktor-faktor dan komponen CAMEL yang dinilai yaitu modal. Modal merupakan salah satu faktor penting bagi bank dalam rangka pengembangan usaha dan menampung risiko kemungkinan kerugian. Permodalan yang cukup adalah berkaitan dengan penyediaan modal sendiri yangdiperlukan, yang mungkin timbul dari penanaman dalam aktiva produktif yang mengandung risiko serta membagi penanaman dalam benda tetap dan investasi.Berdasarkan Peraturan Bank Indonesia No. 8/18/PBI/2006 tanggal 5 Oktober 2006 tentang Kewajiban Penyediaan Modal Minimum BPR menjelaskan rincian modal bagi bank yaitu modal inti, modal pelengkap, ATMR, dan penilaian modal.

Modal inti terdiri atas modal disetor dan cadangan-cadangan yang dibentuk dari laba setelah pajak. Secara rincian modal inti terdiri dari modal disetor, agio saham, modal sumbangan, cadangan umum, cadangan tujuan, laba yang ditahan (rentained earning), laba tahun lalu, dan laba tahun berjalan. Modal inti tersebutharus dikurangi dengangoodwill yang ada dalam pembu- kuan bank dan kekurangan jumlah penyisihan penghapusan aktiva produktif dari jumlah yang sebenarnya dibentuk sesuai dengan ketentuan Bank Indonesia.Modal pelengkap terdiri dari cadangan-cadangan yang dibentuk tidak dari laba setelah pajak, serta pinjaman yang sifatnya dapat dipersamakan dengan modal. Secara rinci modalpelengkap terdiri dari cadangan revaluasi aktiva tetap, cadangan penghapusan aktiva yang diklasifikasikan, modal pinjaman (sebelumnya disebut modal kuasi), pinjaman subordinasi, dan pengertian aktiva.

Aktiva Tertimbang Menurut Risiko (ATMR) yaitu pos-pos aktiva yang diberikan bobot risiko yang terkandung pada aktiva itu sendiri atau bobot risiko yang didasarkan pada golongan nasabah, peminjam atau sifat barang jaminan. Rincian bobot tersebut yaitu, $0 \%$ dikalikan dengan kas, surat Bank Indonesia, kredit yang dijamin dengan saldo deposito berjangka dan tabungan yang cukup milik peminjam pada bank yang bersangkutan. Giro dikalikan dengan $20 \%$, deposito berjangka, sertifikat deposito, tabungan serta tagihan lainnya kepada bank lain, kredit kepada bank lain atau pemerintah daerah dan kredit kepada atau kredit yang dijamin oleh bank lain/ pemerintah daerah.Kredit Pemilikan Rumah (KPR) atau kredit yang dijamin oleh hipotik pertama dengan tujuan untuk dihuni dikalikan dengan 50\%. Kredit kepada atau yang dijamin oleh BUMD dikalikan dengan 100\%, perorangan, koperasi, perusahaan swasta dan lain-lain, aktiva tetap dan investasi (nilai buku), aktiva tetap lainnya yang tersebut diatasdan perhitungan kebutuhan modal minimum.

Dengan membandingkan jumlah modal dengan kewajiban penyediaan modal minimum dapat diketahui kelebihan atau kekurangan modal bank. Adapun penentuan besarnya nilai kredit untuk penilaian permodalan ini yaitu pemenuhan KPMM sebesar 8\% diberi predikat "sehat" dengan nilai sebesar 81 , dan untuk setiap kenaikan 0,1\% dari pemenuhan KPMM sebesar $8 \%$ nilai kredit ditambah 1 hingga maksimal 100 dan pemenuhan KPMM kurang dari $8 \%$ sampai dengan 7,9\% diberi predikat "kurang sehat" dengan nilai kredit 65 , dan setiap penurunan 
Sri Murdiati \& Medi Tri Purwanto / Analisis Kinerja dengan Pendekatan ...

0,1\% dari pemenuhan KPMM sebesar 7,9\% nilai kredit 1 hingga minimum 0 .

Penilaian terhadap faktor permodalan didasarkan pada rasio modal terhadap Aktiva Tertimbang Menurut Risiko (ATMR) sesuai yang dengan yang diatur dalam PBI no. 8/18/ PBI/2006 tentang Kewajiban Modal Minimum BPR tanggal 5 Oktober 2006. Ketentuan rasio antara modal dan ATMR biasa disebut Capital Adquancy Ratio (CAR) atau Rasio Kecukupan Modal yang merupakan analisis solvabilitas untuk mendukung kegiatan bank secara efisien dan mampu menyerap kerugian-kerugian yang tidak dapat dihindarkan serta apakahkekayaan bank semakin bertambah atau semakin berkurang. Rasio Permodalan (CAR) adalah sebagai berikut:

$\mathrm{CAR}=\frac{(\text { Modal Inti }+ \text { Pelengkap })}{\mathrm{ATMR}} \times 100 \%$

Adapun formulasi rasio ini menjadi nilai kredit:

$$
\mathrm{NK}=\frac{(\text { Rasio car })}{0,1} \times(\text { Maksimal100 })
$$
Tabel 1.

Penilaian faktor permodalan terlihat pada

Tabel 1. Kriteria penilaian kesehatan faktorpermodalan

\begin{tabular}{ll}
\hline \multicolumn{1}{c}{ Kriteria } & \multicolumn{1}{c}{ Hasil Rasio } \\
\hline Sehat & $\geq 8 \%$ \\
CukupSehat & $\geq 7,9 \%-<8,0 \%$ \\
KurangSehat & $\geq 6,5 \%-<7,9 \%$ \\
Tidak Sehat & $<6,5 \%$ \\
\hline Sumber: SK DIR BI No. 30/12/KEP/DIR/97
\end{tabular}

Berdasarkan SK Dir BI No. 26/22/KEP/

DIR tanggal 29 Mei 1993 sebagaimana dirubah dalam PBI No. 8/19/PBI/2006 tentang Kualitas Aktiva Produktif dan Pembentukan Penyisihan Penghapusan Aktiva Produktif (PPPAP)
$\mathrm{BPR}$, disebutkan bahwa kinerja dan kelangsungan usaha BPR dipengaruhi oleh kualitas penyediaan dana pada aktiva produktif, termasuk kesiapan untuk menghadapi risiko kerugian dari penyediaan dana tersebut dan dalam rangka mengembangkan usaha dan mengelola risiko, pengurus BPR wajib menjaga kualitas aktiva produktif dan membentuk penyisihan penghapusan aktiva produktif.

Aktiva produktif yaitu semua aktiva dalam rupiah maupun valuta asing yang dimiliki oleh bank dengan maksud untuk memperoleh penghasilan sesuai dengan fungsinya, sehingga kredit merupakan salah satu bentuk aktiva produktif (Susilo, 2000). Adapun komponen dari aktiva produktif terdiri dari kredit yang diberikan, yaitu penyediaan uang atau tagihan yang dapat dipersamakan dengan itu, berdasarkan persetujuan atau kesepakatan pinjam meminjam antaraBPR dengan pihak peminjam yang mewajibkan pihak peminjam untuk melunasi utangnya setelah jangka waktu tertentu dengan pemberian bunga, termasuk pembelian surat berharga nasabah yang dilengkapi dengan Note Purchase Agreement (NPA)dan pengambilalihan tagihan dalam rangka kegiatan anjak piutang.

Surat-surat berharga, yaitu penanaman dalam bentuk Sertifikat Bank Indonesia (SBI), Surat Berharga Pasar Uang (SBPU), dan sahamsaham serta obligasi yang diperdagangkan di pasar modal. Penanaman dana antar bank adalah penanaman dana bank pada bank lain dalam bentuk tabungan, deposito berjangka, sertifikat deposito, kredit yang diberikan dan penanaman dana lainnya yang sejenis baik dalam negeri maupun luar negeri.

Aktiva produktif yang dimiliki bank memiliki empat golongan yaitu lancar, kurang lancar, diragukan dan macet sesuai dengan kolektibilitasnya. Kolektibilitas merupakan keadaan pembayaran kembali pokok dan bunga kredit nasabah serta tingkat kemungkinan diterimanya kembali dana yang ditanamkan dalam surat berharga atau penanaman lainnya.Aktiva Produktif yang diklasifikasikan, yaitu aktiva produktif, baik yang sudah maupun yang mengandung potensi tidak memberikan penghasilan atau menimbul- 
kan kerugian bagi bank. Adapun cara pengklasifikasian ini mengikuti cara kolektibilitas diatur dalam SE BI No. 23/12/BPPP tanggal 28 Desember 1991, yaitu0\% dari aktiva produktif yang digolongkan lancar, 50\% dari aktiva produktif yang digolongkan kurang lancar, 75\% dari aktiva produktifyang digolongkan diragukan, dan $100 \%$ dari aktiva produktif yang digolongkan macet.

Dalam rangka mengantisipasi kemungkinan terjadinya kerugian dari setiap penanaman dana yang dilakukan bank, maka bank wajib membentuk PPAP yang cukup guna menutup kerugian tersebut. Besarnya pembentukan penyisihan sesuai dengan SK DIR BI No. 26/167/KEP/ DIR dan PBI No. 8/19/PBI/2006 tentang KAP dan pembentukan PPAP BPR adalah sekurangkurangnya $0,5 \%$ dari aktiva produktif yang digolongkan lancar, $10 \%$ dari aktiva produktif yang digolongkan kurang lancar setelah dikurangi agunan yang dikuasai, $50 \%$ dari aktiva produktif yang digolongkan diragukan setelah dikurangi agunan yang dikuasai, $100 \%$ dari aktiva produktif yang digolongkan macet setelah dikurangi agunan yang dikuasai.Rasio penilaian terhadap Kualitas Aktiva Produktif yaitu dilihat dari perbandingan aktiva produktif yang diklasifikasikan terhadap total aktiva produktif.

$$
\begin{aligned}
& \text { Rasio KAP } 1=\frac{\begin{array}{c}
\text { aktifa produktif yang } \\
\text { diklasifikasikan }
\end{array}}{\text { total aktiva produk }} \times 100 \\
& \text { Nilai Kredit }(\mathrm{NK})=\frac{22,5 \% \text {-rasio KAP }}{0,15} \times(\text { maksimal 100) }
\end{aligned}
$$

Bobot yang diberikan untuk penilaian ini adalah sebesar $25 \%$ dari keseluruhan penilaian faktor CAMEL.Perbandingan Penyisihan Penghapusan Aktiva Produktif (PPAP) yang dibentuk terhadap Penyisihan Penghapusan Aktiva Produktif yang Wajib Dibentuk (PPAPWD) yang telah ditetapkan oleh Bank Indonesia.

$$
\text { Rasio KAP } 2=\frac{\text { PPAD }}{\text { PPAWD }} \times 100 \%
$$

Nilai Kredit (murni) $=$ n Rasio $\mathrm{x} 1$

Hasil penilaian faktor kualitas aktiva produktif terlihat pada Tabel 2. Menurut SK DIR BI No.30/12/KEP/DIR dan SE BI No. 30/3/ UPPB tanggal 30 April 1997 tentang tata cara penilaian tingkat produktif, manajemen umum, manajemen rentabilitas dan manajemen likuiditas, penilaian faktor manajamen didasarkan pada 25 aspek yang memberikan penekanan pada manajemen umum (10 indikator yang terdiri dari penilaian strategi/sasaran, struktur, sistem, dan kepemimpinan) dengan bobot penilaian $10 \%$ dan manajemen risiko (15 indikator terdiri dari: penilaian risiko likuiditas, risiko kredit, dan risiko operasional) dengan bobot penilaian $10 \%$.

Tata cara penilaian, yaitu dengan menggunakan daftar pertanyaan-pernyataan (sesuai dengan aspek yang dinilai). Skala penilaian untuk setiap indikator antara 0 sampai 4 yaitu jika 0 maka mencerminkan kondisi lemah, 1,2,3 maka mencerminkan kondisi antara dan nilai 4 mencerminkan kondisi baik. Hasil penilaian faktor manajemen terlihat pada Tabel 3.

Tabel 2. Kriteria penilaian tingkat kesehatan faktor KAP

\begin{tabular}{lcc}
\hline \multirow{2}{*}{ Kriteria } & \multicolumn{2}{c}{ Hasil Rasio } \\
\cline { 2 - 3 } & Rasio 1 & Rasio 2 \\
\hline Sehat & $0,00 \%-\leq 10,35 \%$ & $\geq 81,00 \%$ \\
Cukup Sehat & $>10,35 \%-\leq 12,60 \%$ & $\geq 66,00 \%-<81,00 \%$ \\
Kurang Sehat & $>12,60 \%-\leq 14,85 \%$ & $\geq 51,00 \%-<66,00 \%$ \\
Tidak Sehat & $>14,85 \%$ & $<51 \%$ \\
\hline
\end{tabular}

Sumber: SK DIR BI No.30/12/KEP/DIR/97 
Sri Murdiati \& Medi Tri Purwanto / Analisis Kinerja dengan Pendekatan ...

Tabel 3. Kriteria penilaian tingkat kesehatan faktor manajemen

\begin{tabular}{lcc}
\hline Kriteria & $\begin{array}{c}\text { Manajemen } \\
\text { Umum }\end{array}$ & $\begin{array}{c}\text { Manajemen } \\
\text { Risiko }\end{array}$ \\
\hline Sehat & $35-40$ & $49-60$ \\
Cukup Sehat & $27-<35$ & $40-<49$ \\
Kurang & $21-<27$ & $31-<40$ \\
Sehat & $0-<21$ & $0-<31$ \\
Tidak Sehat & & \\
\hline Sumber: SKDIR BINo.30/12/KEP/DIR/97
\end{tabular}

Penilaian terhadap faktor rentabilitas didasarkan pada dua rasio. Rasio pertama adalah rasio laba sebelum pajak terhadap rata-rata volume usaha yang disebut dengan rasio Return on Asset (ROA). Laba sebelum pajak adalah laba yang diperoleh perusahaan 12 bulan terakhir sebelum dikurangi dengan pajak. Sedangkan rata-rata volume usaha adalah total volume usaha perusahaan dalam 12 bulan terakhir dibagi dengan 12 bulan. Bobot untuk penilaian komponen ini adalah 5\% dari keseluruhan penilaian faktor CAMEL.Rasio Biaya Operasional terhadap Pendapatan Operasional :

Nilai Kredit $(\mathrm{NK})=\frac{\text { Rasio ROA }}{0,015} \quad \begin{gathered}(\text { maksimal } \\ 100)\end{gathered}$

Bobot untuk penilaian komponen ini adalah 5\% dari keseluruhan penilaian faktor CAMEL. Rasio Biaya Operasional terhadap Pendapatan Operasional :

$$
\begin{aligned}
& \begin{array}{l}
\text { Rasio Rentabilitas } \\
2 \text { BOPO })
\end{array} \quad=\frac{\text { Biaya operasional }}{\text { Pendapatan operasional }} \times 100 \% \\
& \text { Nilai Kredit }(\mathrm{NK})=\frac{\text { 100-Rasio BOPO }}{0,08}(\text { maksimal 100 })
\end{aligned}
$$

Hasil penilaian faktor rentabilitas terlihat pada Tabel 4. Suatu bank dikatakan likuid apabila bank yang bersangkutan dapat memenuhi kewajiban hutang-hutangnya, dapat membayar semua deposannya, serta dapat memenuhi permintaan kredit yang diajukan tanpa terjadi penangguhan (Mulyono, 1995). Oleh karena itu, bank dikatakan likuid apabila bank tersebut memiliki cash assets sebesar kebutuhan yang akan digunakan untuk memenuhi likuiditasnya, bank tersebut memiliki cash assets yang lebih kecil dari butir satu diatas, tetapi yang bersangkutan juga mempunyai assets lain (khususnya suratsurat berharga) yang dapat dicairkan sewaktuwaktu tanpa mengalami penurunan nilai pasarnya, dan bank tersebut mempunyai kemampuan untuk menciptakan cash asset baru melalui berbagai bentuk hutang.

Penilaian terhadap faktor likuiditas menggunakan dua rasio yang dapat ditampilkan dalam rumus perbandingan antara alat likuid terhadap hutang lancar (Cash Ratio)adalah rasio alat likuid terhadap hutang lancar yang digunakan untuk mengukur kemampuan bank dalam membayar hutang lancarnya dengan menggunakan alat likuidnya.

$$
\text { Cash Ratio }=\frac{\text { Alat Liquid }}{\text { Hutang Lancar }} \times 100 \%
$$

Tabel 4. Kriteria penilaian tingkat kesehatan faktor rentabilitas

\begin{tabular}{lcc}
\hline \multirow{2}{*}{ Kriteria } & \multicolumn{2}{c|}{ Hasil Rasio } \\
\cline { 2 - 3 } & Rasio 1 & Rasio 2 \\
\hline Sehat & $>1,215 \%$ & $\leq 93,52 \%$ \\
Cukup Sehat & $>0,999 \%-\leq 1,215 \%$ & $>93,52 \%-\leq 94,72 \%$ \\
Kurang Sehat & $>0,765 \%-\leq 0,999 \%$ & $>94,72 \%-\leq 95,92 \%$ \\
Tidak Sehat & $\leq 0,765 \%$ & $>95,92 \%$ \\
\hline
\end{tabular}

Sumber: SK DIR BI No. 30/12/KEP/DIR/97 
Nilai Kredit $(\mathrm{NK})=\frac{\text { rasio CR }}{0,05} \begin{gathered}(\text { Maksimal } \\ 100)\end{gathered}$

LDR adalah rasio antara seluruh jumlah kredit yang diberikan bank dengan dana yang diterima oleh bank. Rasio ini menyatakan seberapa jauh kemampuan bank dalam membayar kembali penarikan dana yang dilakukan deposan dengan mengendalikan kredit yang diberikan sebagai sumber likuiditasnya.

$$
\operatorname{LDR}(2)=\frac{\text { kredit yang diberikan }}{\text { Dana yang diterima }} \times 100 \%
$$

Kredit yang dimaksud perhitungan ini meliputi kredit yang diberikan kepada masyarakat dikurangi dengan bagian kredit sindikasi yang dibiayai oleh bank lain, penanaman kepada bank lain dalam bentuk kredit yang diberikan dengan jangka waktu lebih dari tiga bulan dan penanaman kepada bank lain dalam bentuk kredit yang diberikan dalam rangka kredit sindikasi. Dana yang diterima oleh bank meliputi deposito dan tabungan masyarakat pinjaman bukan dari bank lain dengan jangka waktu lebih dari tiga bulan (di luar pinjaman subordinasi), deposito dan pinjaman dari bank lain dengan jangka waktu lebih dari 3 bulan, modal inti dan modal pinjaman. Perhitungan terhadap rasio likuiditas dua dilakukan dengan cara rasio sebesar $115 \%$ atau lebih diberi nilai kredit 0 dan untuk penurunan sebesar $1 \%$ mulai dari $115 \%$ nilai kredit ditambah 4 dengan maksimal 100. Hasil penilaian faktor likuiditas terlihat pada Tabel 5. Nilai kredit $=(115-$ Rasio LDR $) \times 4$

\section{METODE}

Dalam penelitian ini digunakan paradigma kuantitatif, yaitu penelitian yang menekankan pada pengujian teori-teori melalui pengukuran variabel-variabel penelitian dengan angka dan melakukan analisis data yang diperoleh dari hasil wawancara dan penelusuran dari catatan, brosur serta dokumen-dokumen PD. BPR BKK Banjarharjo Kabupaten Brebes. Selanjutnya data-data tersebut dianalisis dengan metode CAMEL. Metode CAMEL merupakan salah satu metode deskriptif untuk menganalisis tingkat kesehatan suatu bank. CAMEL sendiri terdiri dari lima dimensi, pertama adalah C (Capital), A (Asset), M (Management), E (Earning) dan L (Liquidity).

\section{HASIL DAN PEMBAHASAN}

Penilaian permodalan perbankan dalam merupakan kewajiban penyediaan modal minimum $8 \%$ dari ATMR yang telah ditetapkan oleh Bank of Internatioanal Settlements (BIS).Aktiva Tertimbang Menurut Risiko (ATMR) yaitu pospos aktiva yang diberikan bobot resikoyang terkandung pada aktiva itu sendiri.Ketentuan rasio antara modal dan ATMR biasa disebut Capital Adequancy Ratio (CAR) atau Rasio Kecukupan Modal yang merupakan analisis solvabilitas untuk mendukung kegiatan bank secara efisien dan mampu menyerap kerugian-kerugian yang tidak dapat dihindarkan serta apakah kekayaan bank semakin bertambah atau semakin berkurang.

Dari perhitungan yang ditunjukkan pada Tabel 6 dapat diketahui bahwa pada tahun 2008 rasio CAR yang dihasilkan $16,25 \%$ untuk risiko

Tabel 5. Kriteria penilaian tingkat kesehatan faktor likuiditas

\begin{tabular}{lcc}
\hline \multicolumn{1}{c}{ Kriteria } & \multicolumn{2}{c}{ Hasil Rasio } \\
& Rasio 1 & Rasio 2 \\
\hline Sehat & $>4,05 \%$ & $\leq 94,75 \%$ \\
Cukup Sehat & $>3,30 \%-\leq 4,05 \%$ & $>94,75 \%-\leq 98,5 \%$ \\
Kurang Sehat & $>2,55 \%-\leq 3,30 \%$ & $>98,5 \%-\leq 102,25 \%$ \\
Tidak Sehat & $\leq 2,55 \%$ & $>102,25 \%$ \\
\hline
\end{tabular}

Sumber: SK DIR BI No. 30/12/KEP/DIR/97 
Sri Murdiati \& Medi Tri Purwanto / Analisis Kinerja dengan Pendekatan ...

kredit dan CAR untuk risiko kredit dan risiko pasar sebesar 15,29\%. Hal ini berarti bahwa bank mampu menjamin setiap Rp 1.000,00 kerugian yang mungkin akan terjadi dari penanaman modal sendiri sebesar Rp 162,5 untuk risiko kredit dan sebesar Rp 152,9 untuk risiko kredit dan risiko pasar. Berdasarkan kriteria BI, rasio CAR tahun 2008 dinilai sehat karena lebih dari 8\% dan mampu menyediakan dana $16,25 \%$ dan $15,29 \%$ dari ATMR yaitu sebesar Rp 83.494.366 sehingga apabila bank dilikuidasi, bank akan mampu untuk memenuhi kewajibannya.
Dari perhitungan yang ditunjukkan pada Tabel 6 dapat diketahui bahwa pada tahun 2009 rasio CAR yang dihasilkan 19,97\% untuk risiko kredit dan CAR untuk risiko kredit dan risiko pasar sebesar $18,82 \%$. Hal ini berarti bahwa bank mampu menjamin setiap Rp 1.000,00 kerugian yang mungkin akan terjadi dari penanaman modal sendiri sebesar Rp 199,7 untuk risiko kredit dan sebesar Rp 188,2 untuk risiko kredit dan risiko pasar. Berdasarkan kriteria BI, rasio CAR tahun 2009 dinilai sehat karena lebih dari 8\% dan mampu menyediakan dana 19,97\% dan 18,82\%

Tabel 6. Perhitungan Kewajiban Penyediaan Modal Minimum (KPMM) Tahun 2008,2009 dan 2010 (dalam Ribuan Rupiah)

\begin{tabular}{|c|c|c|c|}
\hline Keterangan & Nominal & Nominal & Nominal \\
\hline \multicolumn{4}{|l|}{ I. Modal } \\
\hline 1. Modal Inti & 10.519 .416 & 13.104 .120 & 15.448 .235 \\
\hline 2.Modal Pelengkap & 2.308 .894 & 1.880 .751 & 1.819 .451 \\
\hline Dikurangi : Penyertaan Saham & $(65.859)$ & $(69.941)$ & 17.267 .686 \\
\hline Jumlah Modal Untuk Risiko Kredit & 12.762 .451 & 14.914 .930 & $(208.979)$ \\
\hline $\begin{array}{l}\text { Jumlah Modal untuk Risiko Kredit dan } \\
\text { Risiko Pasar }\end{array}$ & 12.762 .451 & - & 17.058 .707 \\
\hline Modal Minimum untuk Risiko Kredit & 6.282 .208 & 14.914 .930 & 8.190 .594 \\
\hline Modal Minimum untuk Risiko Pasar & 397.341 & 5.975 .258 & 426.284 \\
\hline $\begin{array}{l}\text { Jumlah Modal Minimum ntuk } \\
\text { Risiko Kredit dan Risiko Pasar }\end{array}$ & 6.679 .549 & 365.634 & 8.616 .878 \\
\hline $\begin{array}{l}\text { ATMR untuk Risiko Kredit setelah } \\
\text { memperhitungkan Risiko Spesifik }\end{array}$ & 78.527 .600 & 6.340 .893 & 102.382 .429 \\
\hline ATMR untuk Risiko Pasar & 4.966 .766 & 74.690 .731 & 5.328 .550 \\
\hline $\begin{array}{l}\text { Jumlah ATMR untuk Risiko Kredit dan } \\
\text { Risiko Pasar }\end{array}$ & 83.494 .366 & 4.570 .435 & 107.710 .979 \\
\hline Kelebihan Modal & 6.082 .902 & 79.261 .166 & 8.441 .829 \\
\hline CAR untuk Risiko Kredit & $16,25 \%$ & 8.574 .037 & $16,66 \%$ \\
\hline CAR untuk Risiko Kredit dan Risiko Pasar & $15,29 \%$ & $19,97 \%$ & $15,84 \%$ \\
\hline CAR Minimum & $8,00 \%$ & $18,82 \%$ & $8,00 \%$ \\
\hline Nilai Kredit/NK CAR untuk Risiko Kredit & 164 & $8,00 \%$ & 168 \\
\hline NK Max & 100 & 201 & 100 \\
\hline Nilai Akhir $=$ Bobot $x$ NK & 25 & 100 & 25 \\
\hline \multirow[t]{2}{*}{ Indikator } & Sehat & 25 & Sehat \\
\hline & & Sehat & \\
\hline
\end{tabular}


dari ATMR yaitu sebesar Rp 79.261.166sehingga apabila bank dilikuidasi, bank akan mampu untuk memenuhi kewajibannya.

Dari perhitungan yang ditunjukkan pada Tabel6 dapat diketahui pula bahwa pada tahun 2010 rasio CAR yang dihasilkan 16,66\% untuk risiko kredit dan CAR untuk risiko kredit dan risiko pasar sebesar $15,84 \%$. Hal ini berarti, bahwa bank mampu menjamin setiap Rp 1.000,00 kerugian yang mungkin akan terjadi dari penanaman modal sendiri sebesar Rp 166,6 untuk risiko kredit dan sebesar $\mathrm{Rp}$ 158,4 untuk risiko kredit dan risiko pasar. Berdasarkan kriteria BI, rasioCAR tahun 2010 dinilai sehat karena lebih dari $8 \%$ dan mampu menyediakan dana 16,66\% dan 15,84\% dari ATMR yaitu sebesar Rp 107.710.979sehingga apabila bank dilikuidasi, bank akan mampu untuk memenuhi kewajibannya.

Seperti ditunjukkan pada Tabel 6, bahwa perkembangan KPMM PD. BPR BKK Banjarharjo selama periode 2008 sampai dengan 2010 menunjukkan penurunan kinerja, penurunan ini terjadi karena adanya perluasan usaha serta semakin meningkatnya pembiayaan yang dilakukan oleh PD. BPR BKK Banjarharjo. Sehingga menyebabkan modal yang dimilik PD. BPR BKK Banjarharjo mengalami penurunan secara persentasenya, meskipun jika dilihat dari nominalnya mengalami kenaikan. Selain itu ATMR PD. BPR BKK Banjarharjo juga mengalami kenaikan yang persentasenya lebih besar dari pada kenaikan modal setiap tahunnya, yang mengakibatkan beban PD. BPR BKK Banjarharjo untuk menanggung jika terjadi kerugian juga semakin tinggi. Hal inilah yang menyebabkan terjadinya penurunan kinerja KPMM PD. BPR BKK Banjarharjo selama periode 2008 sampai dengan 2010.

Dalam penilaian aspek kualitas aktiva produktif rasio yang digunakan untuk mengkuantifikasi aktiva produktif didasarkan pada dua rasio yaiturasio aktiva produktif Yang diklasifikasikan terhadap total aktiva produktif atau rasio KAP (Kualitas Aktiva Produktif). Rasio ini digunakan untuk mengetahui kualitas aktiva produktif, yaitu penanaman dana bank dalam rupiah atau valuta asing dalam bentuk kredit, surat berharga, penempatan pada bank lain dan penyertaan. Penilaian tersebut dilakukan untuk melihat apakah aktiva produktif digunakan untuk menghasikan laba secara maksimal. Selain itu penilaian kualitas aset dimaksudkan untuk menilai kondisi aset bank, termasuk antisipasi atasrisiko gagal bayar dari pembiayaan (credit risk) yang akan muncul.

Tahun 2008 rasio yang dihasilkan sebesar $8,05 \%$. Hal ini berarti setiap Rp 1.000,00 dana yang ditanamkan pada aktiva produktif terdapat risiko kegagalan pengembalian kredit sebesar Rp 80,5. Dari aktiva produktif bank mengambil bunga sebesar 35\% per tahun, jadi tingkat pengembalian kredit padaPD. BPR BKK Banjarharjo dinilai baikkarena selisih antara bunga per tahun dengan persentase risiko gagalnya pengembalian kredit masih terdapat 26,95\% dari total aktiva produktif yang akan diterima sebagai pendapatan operasional. Berdasarkan kriteria BI, maka kualitas aktiva produktif pada PD. BPR BKK Banjarharjo dinilai sehatkarena kurang dari 10,35\% sesuai dengan standar penilaian Bank Indonesia.

Tahun 2009 rasio yang dihasilkan sebesar 3,06\%. Hal ini berarti setiap Rp 1.000,00 dana yang ditanamkan pada aktiva produktif terdapat risiko kegagalan pengembalian kredit sebesar Rp 30,6. Dari aktiva produktif bank mengambil bunga sebesar 35\% per tahun, jadi tingkat pengembalian kredit padaPD. BPR BKK Banjarharjo dinilai baikkarena selisih antara bunga per tahun dengan persentase risiko gagalnya pengembalian kredit masih terdapat 31,94\% dari total aktiva produktif yang akan diterima sebagai pendapatan operasional. Berdasarkan kriteria BI, maka kualitas aktiva produktif pada PD. BPR BKK Banjarharjo dinilai sehatkarena kurang dari 10,35\% sesuai dengan standar penilaian Bank Indonesia.

Tahun 2010 rasio yang dihasilkan sebesar $2,22 \%$. Hal ini berarti setiap Rp 1.000,00 dana yang ditanamkan pada aktiva produktif terdapat risiko kegagalan pengembalian kredit sebesar Rp 22,2. Dari aktiva produktif bank mengambil bunga sebesar 35\% per tahun, jadi tingkat 
Sri Murdiati \& Medi Tri Purwanto / Analisis Kinerja dengan Pendekatan ...

Tabel 7. Perhitungan Rasio Kualitas Aktiva Produktif (KAP) (dalam Ribuan Rupiah)

\begin{tabular}{lccc}
\hline \multicolumn{1}{c}{ Pos - pos } & \multicolumn{3}{c}{ Tahun } \\
\cline { 2 - 4 } & $\mathbf{2 0 0 8}$ & $\mathbf{2 0 0 9}$ & $\mathbf{2 0 1 0}$ \\
\hline APYD & 5.528 .481 & - & \\
Dalam Perhatian Khusus & 998.587 & 812.930 & 836.233 \\
Kurang lancer & 1.372 .983 & 941.398 & 580.928 \\
Diragukan & 1.271 .873 & 2.598 .669 & 2.502 .282 \\
Macet & 113.904 .635 & 142.245 .897 & 176.413 .803 \\
Total Aktiva Produktif & $8,05 \%$ & $3,06 \%$ & $2,22 \%$ \\
Rasio KAP & 50 & 83 & 89 \\
Nilai Kredit (NK) & 100 & 100 & 100 \\
NK Max & 12,5 & 20,75 & 22,25 \\
Nilai Akhir $=$ Bobot $x$ NK & Sehat & Sehat & Sehat \\
Indikator & & & \\
\hline
\end{tabular}

pengembalian kredit pada PD. BPR BKK Banjarharjo dinilai baik karena selisih antara bunga per tahun dengan persentase risiko gagalnya pengembalian kredit masih terdapat 32,78\% dari total aktiva produktif yang akan diterima sebagai pendapatan operasional. Berdasarkan kriteria BI, maka kualitas aktiva produktif pada PD. BPR BKK Banjarharjo dinilai sehat karena kurang dari 10,35\% sesuai dengan standar penilaian Bank Indonesia.

Selanjutnya, dalam penilaian aspek kualitas aktiva produktif rasio yang digunakan untuk mengkuantifikasi aktiva produktif didasarkan pada rasio penyisihan penghapusan aktiva produktif terhadap penyisihan penghapusan aktiva produktif yang wajib dibentuk.Rasio ini mengukur pemenuhan PPAP yang dibentuk bank terhadap PPAPWD yang ditetapkan Bank Indonesia sehubungan dengan adanya kewajiban bank untuk membentuk PPAP yang cukup untuk menutup resiko kemungkinan yang timbul dari penanaman aktiva produktifnya.

Tahun 2008 rasio yang dihasilkan sebesar $123,6 \%$. Hal ini berarti bahwa dari setiap Rp 1.000,00 PPAPWD yang ditetapkan oleh BI, makaPD. BPR BKK Banjarharjo mampu untuk menyediakan dana penghapusan piutang sebesar Rp 1.236,00 dan terdapat keuntungan Rp 236 dan keuntungan tersebut secara langsung akan mempengaruhi jumlah laba yang akan diperoleh pihak bank. Berdasarkan SK DIR BI No. 30/12/KEP/DIR/97, maka kualitas PPAP pada PD. BPR BKK Banjarharjodinilai sehatkarena lebih dari $81,00 \%$ dari standar penilaian $\mathrm{BI}$.

Tahun 2009 rasio yang dihasilkan sebesar $105,2 \%$. Hal ini berarti bahwa dari setiap Rp 1.000,00 PPAPWD yang ditetapkan oleh BI, maka PD. BPR BKK Banjarharjo mampu untuk menyediakan dana penghapusan piutang sebesar Rp 1.052,00 dan terdapat keuntungan $\mathrm{Rp}$ 52,00 dan keuntungan tersebut secara langsung akan mempengaruhi jumlah laba yang akan diperoleh pihak bank. Berdasarkan SK DIR BI No. 30/12/KEP/DIR/97, maka kualitas PPAP pada PD. BPR BKK Banjarharjodinilai sehatkarena lebih dari $81,00 \%$ dari standar penilaian $\mathrm{BI}$.

Tahun 2010 rasio yang dihasilkan sebesar 96,1\%. Hal ini berarti bahwa dari setiap Rp 1.000,00 PPAPWD yang ditetapkan oleh BI, makaPD. BPR BKK Banjarharjomampu untuk menyediakan dana penghapusan piutang sebesar Rp 961,00, namun masih terdapat kerugian Rp 39,00 dan kerugian tersebut secara langsung akan mempengaruhi jumlah laba yang akan diperoleh pihak bank. Berdasarkan SK DIR BI No. 30/12/KEP/DIR/97, maka kualitas PPAP pada PD. BPR BKK Banjarharjodinilai sehatkarena lebih dari $81,00 \%$ dari standar penilaian BI. 
Jurnal Dinamika Manajemen, 5 (1) 2014,12-30

Tabel 8. Perhitungan Rasio PPAP terhadap PPAPWD ( dalam Ribuan Rupiah )

\begin{tabular}{lccc}
\hline & Pos - pos & \multicolumn{3}{c}{ Tahun } \\
\cline { 2 - 4 } & $\mathbf{2 0 0 8}$ & $\mathbf{2 0 0 9}$ & $\mathbf{2 0 1 0}$ \\
\hline Kriteria PPAPYD & & & \\
Kurang lancar & 893.619 & 799.330 & 826.047 \\
Diragukan & 1.359 .220 & 936.183 & 549.685 \\
Macet & 1.263 .390 & 2.574 .745 & 2.491 .017 \\
Jumlah & 3.516 .229 & 4.310 .258 & 3.866 .749 \\
PPAPWD & 2.844 .086 & 4.095 .685 & 4.024 .470 \\
Rasio PPAP & $123,6 \%$ & $105,2 \%$ & $96,1 \%$ \\
NK = Rasio x 1 & 123,6 & 105,2 & 96,1 \\
NK Max & 100 & 100 & 100 \\
Nilai Akhir $=$ Bobot $x$ NK & 5 & 5 & 4,805 \\
Indikator & Sehat & Sehat & Sehat \\
\hline
\end{tabular}

Dalam penilaian rentabilitas faktor-faktor yang diperlukan dalam perhitungan adalah total aktiva dan laba itu sendiri. Rentabilitas adalah kemampuan bank dalam menghasilkan laba selama periode tertentu. Rasio laba sebelum pajak dalam 12 bulan terakhir terhadap rata-rataTotal Assetsdalam 12 bulan terakhir (ROA), dengan perhitungan yaitu untuk rasio 0 atau negatif diberi nilai kredi dan untuk setiap kenaikan 0,015\% mulai dari $0 \%$ nilai kredit ditambah 1 dengan maksimal 100. Rasio ini menunjukkan seberapa besar kemampuan PD. BPR BKK Banjarharjodalam menghasilkan laba sebelum pajak dengan total asset yang dimilikinya.

Tahun 2008 rasio yang dihasilkan sebesar $54,8 \%$. Hal ini menunjukkan bahwa setiap Rp. $1.000,00$ modal yang ditanamkan pada aktiva produktif mampu untuk menghasilkan laba sebesar Rp 548,00. Berdasarkan SK DIR BI No. 30/12/KEP/DIR/97, maka ROA padaPD.BPR BKK Banjarharjoberada dalam kondisi sehat karena lebih dari $1,215 \%$ standar penilaian $\mathrm{BI}$. Tahun 2009 rasio yang dihasilkan sebesar 45,8\%. Hal ini menunjukkan bahwa setiap Rp. 1.000,00 modal yang ditanamkan pada aktiva produktif mampu untuk menghasilkan laba sebesar Rp 458. Berdasarkan SK DIR BI No. 30/12/KEP/ DIR/97, maka ROA pada PD. BPR BKK Banjarharjoberada dalam kondisi sehatkarena lebih dari 1,215\% standar penilaian BI.

Tahun 2010 rasio yang dihasilkan sebesar 45,8\%. Hal ini menunjukkan bahwa setiap Rp. $1.000,00$ modal yang ditanamkan pada aktiva produktif mampu untuk menghasilkan laba sebesar Rp 458,00. Berdasarkan SK DIR BI No. 30/12/KEP/DIR/97, maka ROA pada PD. BPR BKK Banjarharjoberada dalam kondisi sehatkarena lebih dari 1,215\% standar penilaian BI yaitu rasio beban operasional terhadap pendapatan operasional, dengan perhitungan yaitu untuk rasio $100 \%$ atau lebih diberi nilai kredit 0 dan untuk setiap penurunan sebesar 0,08\% mulai dari $100 \%$ nilai kredit ditambah 1 dengan maksimal 100.

Rasio ini menunjukkan persentase beban operasional terhadap pendapatan operasional. Semakin besar persentase rasio berarti semakin besar beban operasional yang terdapat dalam setiap pendapatan operasional. Hasil perhitungan rasio beban operasional terhadap pendapatan operasional terlihat pada Tabel 10.

Tahun 2008 rasio yang dihasilkan sebesar $71,31 \%$. Hal ini berarti untuk memperoleh pendapatan operasional sebesar $\mathrm{Rp} 1.000,00$ makaPD. BPR BKK Banjarharjoharus mengeluarkan biaya operasional sebesar Rp 713,1. Berdasarkan SK DIR BI No. 30/12/KEP/DIR/97, maka rasio BOPO PD. BPR BKK Banjarharjo- 
Sri Murdiati \& Medi Tri Purwanto / Analisis Kinerja dengan Pendekatan ...

dinilai sehatkarena rasionya kurang dari 93,52\% standar penilaian BI. Tahun 2009 rasio yang dihasilkan sebesar 74,40\%. Hal ini berarti untuk memperoleh pendapatan operasional sebesar Rp 1.000,00 makaPD. BPR BKK Banjarharjoharus mengeluarkan biaya operasional sebesar Rp 744. Berdasarkan SK DIR BI No. 30/12/ $\mathrm{KEP} / \mathrm{DIR} / 97$, maka rasio BOPOPD. BPR BKK Banjarharjo dinilai sehat karena rasionya kurang dari $93,52 \%$ standar penilaian BI.

Tahun 2010 rasio yang dihasilkan sebesar 69,85\%. Hal ini berarti untuk memperoleh pendapatan operasional sebesar Rp 1.000,00 maka PD. BPR BKK Banjarharjoharus mengeluarkan biaya operasional sebesar Rp 698,5. Berdasarkan SK DIR BI No. 30/12/KEP/DIR/97, maka rasio BOPOPD. BPR BKK Banjarharjodinilai sehatkarena rasionya kurang dari 93,52\% standar penilaian $\mathrm{BI}$.
Penilaian terhadap faktor likuiditas didasarkan pada rasio yaitu rasio kredit yang diberikan terhadap dana yang diterima oleh bank (LDR). Rasio yang digunakan untuk menilai likuiditas suatu bank dengan cara membagi jumlah kredit yang diberikan oleh bank terhadap dana masyarakat.Adapun perhitungan rasio kredit terhadap dana yang diterimayaitu untuk rasio $115 \%$ atau lebih diberi nilai 0 dan untuk setiap penurunan $1 \%$ nilai kredit dikalikan 4 dengan maksimal 100.

Tahun 2008 rasio yang dihasilkan sebesar $58,54 \%$. Hal ini berarti setiap Rp 1.000,00 dana yang diterima bank mampu untuk menyalurkan kembali pada masyarakat dalam bentuk kredit sebesar Rp 585,4. Berdasarkan SK DIR BI No. 30/12/KEP/DIR/97, maka rasio LDR pada PD. BPR BKK Banjarharjodinilai sehatkarena rasionya kurang dari $94,75 \%$ standar penilaian

Tabel 9. Perhitungan Rasio Laba Sebelum Pajak Terhadap Rata - rata Total Asset (dalam Ribuan Rupiah)

\begin{tabular}{lccc}
\hline \multirow{2}{*}{ Keterangan } & \multicolumn{3}{c}{ Tahun } \\
\cline { 2 - 4 } & $\mathbf{2 0 0 8}$ & $\mathbf{2 0 0 9}$ & $\mathbf{2 0 1 0}$ \\
\hline a) Laba/Rugi Sebelum Pajak & 5.607 .952 & 5.906 .721 & 7.780 .074 \\
b) Rata - rata Total Asset & 10.231 .298 & 12.893 .791 & 16.977 .912 \\
c) Rasio (a : b) x 100\% & $54,8 \%$ & $45,8 \%$ & $45,8 \%$ \\
NK = c : 0,015 $\%$ & 3653 & 3053 & 3053 \\
NK Max & 100 & 100 & 100 \\
Nilai Akhir = Bobot x NK & 5 & 5 & 5 \\
Indikator & Sehat & Sehat & Sehat \\
\hline
\end{tabular}

Tabel 10. Perhitungan Rasio Beban Operasional Terhadap Pendapatan Operasional (dalam Ribuan Rupiah)

\begin{tabular}{lccc}
\hline \multirow{2}{*}{ Keterangan } & \multicolumn{3}{c}{ Tahun } \\
\cline { 2 - 4 } & $\mathbf{2 0 0 8}$ & $\mathbf{2 0 0 9}$ & $\mathbf{2 0 1 0}$ \\
\hline a) Beban Operasional & 13.206 .891 & 16.819 .580 & 17.506 .329 \\
b) Pendapatan Operasional & 18.519 .200 & 22.604 .199 & 25.062 .332 \\
c) Rasio $(\mathrm{a}: \mathrm{b})$ ) $100 \%$ & $71,31 \%$ & $74,40 \%$ & $69,85 \%$ \\
NK $=100 \%$ - c $: 0,08 \%$ & 359 & 320 & 377 \\
NKMax & 100 & 100 & 100 \\
Nilai Akhir $=$ Bobot x NK & 5 & 5 & 5 \\
Indikator & Sehat & Sehat & Sehat \\
\hline
\end{tabular}


BI. Tahun 2009 rasio yang dihasilkan sebesar $53,76 \%$. Hal ini berarti setiap Rp 1.000,00 dana yang diterima bank mampu untuk menyalurkan kembali pada masyarakat dalam bentuk kredit sebesar Rp 537,6. Berdasarkan SK DIR BI No. 30/12/KEP/DIR/97, maka rasio LDR pada PD. BPR BKK Banjarharjodinilai sehat karena rasionya kurang dari $94,75 \%$ standar penilaian BI. Tahun 2010 rasio yang dihasilkan sebesar 49,18\%. Hal ini berarti setiap Rp 1.000,00 dana yang diterima bank mampu untuk menyalurkan kembali pada masyarakat dalam bentuk kredit sebesarRp 491,8. Berdasarkan SK DIR BI No. 30/12/KEP/DIR/97, maka rasio LDR pada PD. BPR BKK Banjarharjodinilai sehatkarena rasionya kurang dari $94,75 \%$ standar penilaian BI.

Selanjutnya, yaitu rasio kewajiban bersih antar bank terhadap modal inti (Cash Ratio).Rasio ini digunakan untuk mengetahui persentase kemampuan bank dalam memenuhi kewajiban jangka pendeknya. Adapun perhitungan rasio kewajiban bersih antar bank terhadap modal inti yaitu untuk rasio $0 \%$ diberi nilai 0 dan untuk setiap penurunan $0,1 \%$ nilai kredit ditambah 1 dengan maksimal 100.
Berdasarkan SKDIR BI No. 30/12/KEP/ DIR/97, maka Cash Ratio pada PD. BPR BKK Banjarharjodinilai sehatkarena rasionya lebih dari 4,05\% standar penilaian Bank Indonesia. Dalam penelitian ini faktor sensitivitas terhadap resiko pasar diproksikan dengan resiko suku bunga yang merupakan variabel yang paling dominan dalam menilai resiko pasar. Resiko bunga merupakan potensi timbulnya kerugian akibat bergeraknya suku bunga pasar kearah yang berlawanan dengan portofolio pasar. Formula yang digunakan yaitu dapat dilihat dalam Tabel 13.

Interest risk ratio (IRR) merupakan rasio yang digunakan untuk mengukur kemungkinan bunga yang diterima oleh bank lebih kecil dibandingkan dengan bunga yang dibayar oleh bank. Pengaruh perubahan tingkat bunga terhadap pendapatan bunga bersih pada bank secara umum tergantung pada pendapatan bunga dan beban bunga. Semakin besar nilai interest risk ratio yang dicapai maka menunjukan arah yang positif dalam menghadapi risiko pasar.

Setelah perhitungan kelima indikator tingkat kesehatan bank pada BRI Unit Kubangwungu, hasil perhitungan kelima indikator tersebut dikalikan dengan bobot masing-masing indika-

Tabel 11. Perhitungan Kredit Yang Diberikan Terhadap Dana Yang Diterima Oleh Bank (dalam Ribuan Rupiah)

\begin{tabular}{lccc}
\hline \multirow{2}{*}{ Keterangan } & \multicolumn{3}{c}{ Tahun } \\
\cline { 2 - 4 } & Kredit Yang Diberikan & $\mathbf{2 0 0 9}$ & $\mathbf{2 0 1 0}$ \\
\hline Kredit Yang Diberikan & 69.503 .859 & 82.541 .885 & 105.923 .763 \\
\hline \multicolumn{4}{c}{ Dana Yang Diterima } \\
\hline Giro & 26.737 .752 & 42.065 .576 & 69.123 .284 \\
Tabungan & 49.372 .027 & 58.307 .624 & 72.299 .927 \\
Deposito Berjangka & 30.289 .801 & 38.294 .731 & 56.138 .262 \\
Pinjaman Yang Diterima & 1.799 .919 & 1.764 .607 & 2.382 .277 \\
Sertifikat Deposito & 564 & 1.892 & - \\
Modal Inti & 10.519 .416 & 13.104 .120 & 15.448 .235 \\
Jumlah & 118.719 .479 & 153.538 .550 & 215.391 .985 \\
Rasio LDR & $58,54 \%$ & $53,76 \%$ & $49,18 \%$ \\
NK = (115 - Rasio) $x$ 4 & 225,84 & 244,96 & 263,28 \\
NK Max & 100 & 100 & 100 \\
Nilai Akhir $=$ Bobot $x$ NK & 5 & 5 & 5 \\
\hline Indikator & Sehat & Sehat & Sehat \\
\hline
\end{tabular}


Sri Murdiati \& Medi Tri Purwanto / Analisis Kinerja dengan Pendekatan ...

tor, kemudian nilai kredit tersebut dapat dikurangi dengan nilai kredit yang berasal dari ketentuan tingkat kesehatan bank yang ditetapkan BI. Adapun penilaian secara keseluruhan selama tahun 2008 sampai 2010 dapat dilihat pada Tabel 14 sampai Tabel 16.

Dari Tabel 14, maka dapat diketahui bahwa tingkat kesehatan bank pada PD. BPR BKK Banjarharjopada tahun 2008 memiliki bobot $62,5 \%$ yang berarti kurang sehat. Berdasarkan kriteria penggolongan tingkat kesehatan pada SK DIR BI No. 30/12/KEP/DIR/97 dalam Permodalan 16,25\% menunjukkan kriteria sehat, karena nilai PPAP yang tinggi sehingga mengakibatkan modal inti menjadi bertambah. ATMR cenderung mengalami peningkatan yang dapat diimbangi oleh modal inti yang diperoleh dengan cara menambah modal dari pemilik, cadangan dana operasional, cadangan likuid kebutuhan kas jangka pendek dan cadangan kesejahteraan karyawan. Peningkatan ATMR yang terjadi menyebabkan meningkat pula resiko yang terjadi pada aktiva yang dimiliki oleh bank.

Rasio KAP sebesar 8,05\% menunjukkan kriteria sehat, artinya PD. BPR BKK Banjarharjomampu untuk mengatasi risiko usaha yang terkandung pada komponen kredit yang diberikan apabila nasabah debitur gagal mengembalikan sebagian atau seluruhnya kredit yang diterima dari bank. Rasio PPAP sebesar 123,6\% menunjukkan kriteria sehat, artinya PD. BPR BKK Banjarharjodalam penyediaan dana untuk PPAP cukup besar, apabila terjadi kerugian akibat penanaman aktiva produktif maka bank mampu untuk menutup kerugian tersebut sehingga laba yang dihasilkan menjadi berkurang sebesar kerugian yang telah tertutup oleh PPAP yang dibentuk oleh bank tersebut.

ROA sebesar 54,8\% menunjukkan kriteria sehat, artinya biaya operasional pada PD. BPR BKK Banjarharjodapat seimbang dengan pendapatan operasional yang diperoleh sehingga bank memperoleh laba yang cukup besar. Rasio BOPO sebesar 71,31\% menunjukkan kriteria sehat, artinya pendapatan operasional yang dihasilkan pada PD. BPR BKK Banjarharjolebih besar daripada biaya operasional yang ditanggung oleh bank.

Cash Ratio sebesar 54,35\% menunjukkan kriteria sehat, artinya PD. BPR BKK Banjarharjomemiliki kemampuan dalam mengelola asset yang digunakan untuk membayar kewajiban yang

Tabel 12. Perhitungan Kewajiban Bersih Antar Bank terhadap Modal Inti (dalam Ribuan Rupiah)

\begin{tabular}{lccc}
\multicolumn{1}{c}{ Keterangan } & \multicolumn{3}{c}{ Tahun } \\
\cline { 2 - 4 } & $\mathbf{2 0 0 8}$ & $\mathbf{2 0 0 9}$ & $\mathbf{2 0 1 0}$ \\
\hline Kewajiban Bersih Antar Bank & 5.717 .701 & 6.282 .867 & 9.977 .575 \\
Modal Inti & 10.519 .416 & 13.104 .120 & 15.448 .235 \\
Cash Ratio & $54,35 \%$ & $47,95 \%$ & $64,59 \%$ \\
Nilai Kredit (NK) & 543,5 & 479,5 & 645,9 \\
NK Max & 100 & 100 & 100 \\
Nilai Akhir = Bobot x NK & 5 & 5 & 5 \\
Indikator & Sehat & Sehat & Sehat \\
\hline
\end{tabular}

Tabel 13. Perhitungan Pendapatan Bunga terhadap Beban Bunga (dalam Ribuan Rupiah)

\begin{tabular}{lccc}
\hline \multirow{2}{*}{ Keterangan } & \multicolumn{3}{c}{ Tahun } \\
\cline { 2 - 4 } & $\mathbf{2 0 0 8}$ & $\mathbf{2 0 0 9}$ & $\mathbf{2 0 1 0}$ \\
\hline a) Pendapatan Bunga & 17.253 .712 & 21.070 .537 & 23.240 .631 \\
b) Beban Bunga & 4.816 .770 & 7.281 .182 & 6.544 .059 \\
Rasio IRR $=(\mathrm{a}):(\mathrm{b}) * 100 \%$ & 358 & 289 & 355 \\
\hline
\end{tabular}


harus dibayar pada waktunya. Rasio LDR sebesar 58,54\% menunjukkan kriteriasehat, artinya dana yang diterima oleh PD. BPR BKK Banjarharjomengalami peningkatan, baik dari tabungan, deposito berjangka, modal inti yang berarti kemampuan bank dalam menyalurkan kreditnya meningkat.

Dari Tabel 15, maka dapat diketahui bahwa tingkat kesehatan bank pada PD. BPR BKK Banjarharjopada tahun 2009 memiliki bobot 70,75 yang berarti cukup sehat. Berdasarkan kriteria penggolongan tingkat kesehatan pada SK DIR BI No. 30/12/KEP/DIR/97 dalam Permodalan 19,97\% menunjukkan kriteria sehat, karena nilai PPAP yang tinggi sehingga mengakibatkan modal inti menjadi bertambah. ATMR cenderung mengalami peningkatan yang dapat diimbangi oleh modal inti yang diperoleh dengan cara menambah modal dari pemilik, cadangan dana operasional, cadangan likuid kebutuhan kas jangka pendek dan cadangankesejahteraan karyawan. Peningkatan ATMR yang terjadi menyebabkan meningkat pula resiko yang terjadi pada aktiva yang dimiliki oleh bank.

Rasio KAP sebesar 3,06\% menunjukkan kriteria sehat, artinyaPD. BPR BKK Banjarharjo mampu untuk mengatasi risiko usaha yang terkandung pada komponen kredit yang diberikan apabila nasabah debitur gagal mengembalikan sebagian atau seluruhnya kredit yang diterima dari bank. Rasio PPAP sebesar $105,2 \%$ menunjukkan kriteria sehat, artinya PD. BPR BKK Banjarharjodalam penyediaan dana untuk PPAP cukup besar, apabila terjadi kerugian akibat penanaman aktiva produktif maka bank mampu untuk menutup kerugian tersebut sehingga laba yang dihasilkan menjadi berkurang sebesar kerugian yang telah tertutup oleh PPAP yang dibentuk oleh bank tersebut.

ROA sebesar 45,8\% menunjukkan kriteria sehat, artinya biaya operasional pada PD. BPR BKK Banjarharjodapat seimbang dengan pendapatan operasional yang diperoleh sehingga bank memperoleh laba yang cukup besar. Rasio BOPO sebesar 74,40\% menunjukkan kriteria sehat, artinya pendapatan operasional yang dihasilkan pada PD. BPR BKK Banjarharjolebih besar daripada biaya operasional yang ditanggung oleh bank.

Cash Ratio sebesar 47,95\% menunjukkan kriteria sehat, artinya PD. BPR BKK Banjarharjomemiliki kemampuan dalam mengelola asset yang digunakan untuk membayar kewajiban yang harus dibayar pada waktunya. Rasio LDR sebesar 53,76\% menunjukkan kriteria sehat, artinya dana yang diterima oleh PD. BPR BKK

Tabel 14. Kuantitatif Perhitungan Tingkat Kesehatan Bank Pada PD. BPR BKK Banjarharjo

Tahun 2008

\begin{tabular}{|c|c|c|c|c|c|c|}
\hline Komponen & Rasio & NK & $\begin{array}{c}\text { NK } \\
\text { Max }\end{array}$ & Bobot & $\begin{array}{l}\text { Nilai } \\
\text { Akhir }\end{array}$ & Indikator \\
\hline \multicolumn{7}{|l|}{ Permodalan } \\
\hline Rasio CAR & $16,25 \%$ & 164 & 100 & $25 \%$ & 25 & Sehat \\
\hline \multicolumn{7}{|l|}{ Kualitas Aktiva Produktif } \\
\hline 1. Rasio KAP & $8,05 \%$ & 50 & 100 & $25 \%$ & 12,5 & Sehat \\
\hline 2. Rasi PPAP & $123,6 \%$ & 123,6 & 100 & $5 \%$ & 5 & Sehat \\
\hline \multicolumn{7}{|l|}{ Rentabilitas } \\
\hline 1. ROA & $54,8 \%$ & 3653 & 100 & $5 \%$ & 5 & Sehat \\
\hline 2. BOPO & $71,31 \%$ & 359 & 100 & $5 \%$ & 5 & Sehat \\
\hline \multicolumn{7}{|l|}{ Likuiditas } \\
\hline 1. Cash Ratio & $54,35 \%$ & 543,5 & 100 & $5 \%$ & 5 & Sehat \\
\hline 2. $\mathrm{LDR}$ & $58,54 \%$ & 225,84 & 100 & $5 \%$ & 5 & Sehat \\
\hline Total Nilai & & & & & 62,5 & Kurang Sehat \\
\hline
\end{tabular}


Sri Murdiati \& Medi Tri Purwanto / Analisis Kinerja dengan Pendekatan ...

Banjarharjo mengalami peningkatan, baik dari tabungan, deposito berjangka, modal inti yang berarti kemampuan bank dalam menyalurkan kreditnya meningkat.

Dari Tabel 16, maka dapat diketahui bahwa tingkat kesehatan bank pada BRI Unit Kubangwungu pada tahun 2010 memiliki bobot 72,055 yang berarti cukup sehat. Berdasarkan kriteria penggolongan tingkat kesehatan pada SK DIR BI No. 30/12/KEP/DIR/97 dalam Permodalan 16,66\% menunjukkan kriteria sehat, karena nilai PPAP yang tinggi sehingga mengakibatkan modal inti menjadi bertambah. ATMR cenderung mengalami peningkatan yang dapat diimbangi oleh modal inti yang diperoleh dengan cara menambah modal dari pemilik, cadangan dana operasional, cadangan likuid kebutuhan kas jangka pendek dan cadangan kesejahteraan karyawan. Peningkatan ATMR yang terjadi menyebabkan meningkat pula resiko yang terjadi pada aktiva yang dimiliki oleh bank.

Rasio KAP sebesar 2,22\%menunjukkan kriteria sehat, artinya PD. BPR BKK Banjarharjomampu untuk mengatasi risiko usaha yang terkandung pada komponen kredit yang diberikan apabila nasabah debitur gagal mengembalikan sebagian atau seluruhnya kredit yang diterima dari bank. Rasio PPAP sebesar
96,1\% menunjukkan kriteria sehat, artinya PD. BPR BKK Banjarharjodalam penyediaan dana untuk PPAP cukup besar, apabila terjadi kerugian akibat penanaman aktiva produktif maka bank mampu untuk menutup kerugian tersebut sehingga laba yang dihasilkan menjadi berkurang sebesar kerugian yang telah tertutup oleh PPAP yang dibentuk oleh bank tersebut.

ROA sebesar 45,8\% menunjukkan kriteria sehat, artinya biaya operasional pada PD. BPR BKK Banjarharjo dapat seimbang dengan pendapatan operasional yang diperoleh. Rasio BOPO sebesar 69,85\% menunjukkan kriteria sehat, artinya pendapatan operasional yang dihasilkan pada BRI Unit Kubangwungu lebih besar daripada biaya operasional yang ditanggung oleh bank.

Cash Ratio sebesar 64,59\% menunjukkan kriteria sehat, artinya PD. BPR BKK Banjarharjo memiliki kemampuan dalam mengelola asset yang digunakan untuk membayar kewajiban yang harus dibayar pada waktunya. Rasio LDR sebesar 49,18\% juga menunjukkan kriteria sehat, artinya dana yang diterima oleh PD. BPR BKK Banjarharjo mengalami peningkatan, baik dari tabungan, deposito berjangka, modal inti yang berarti kemampuan bank dalam menyalurkan kreditnya meningkat.

Tabel 15. Kuantitatif Perhitungan Tingkat Kesehatan Bank Pada PD. BPR BKK Banjarharjo Tahun 2009

\begin{tabular}{lcccccc}
\hline \multicolumn{1}{c}{ Komponen } & Rasio & NK & $\begin{array}{c}\text { NK } \\
\text { Max }\end{array}$ & Bobot & $\begin{array}{c}\text { Nilai } \\
\text { Akhir }\end{array}$ & Indikator \\
\hline $\begin{array}{l}\text { Permodalan } \\
\text { Rasio CAR }\end{array}$ & $19,97 \%$ & 201 & 100 & $25 \%$ & 25 & Sehat \\
$\begin{array}{l}\text { Kualitas Aktiva Produktif } \\
\text { 1. Rasio KAP }\end{array}$ & $3,06 \%$ & 83 & 100 & $25 \%$ & 20,75 & Sehat \\
$\begin{array}{l}\text { 2. Rasi PPAP } \\
\text { Rentabilitas }\end{array}$ & $105,2 \%$ & 105,2 & 100 & $5 \%$ & 5 & Sehat \\
$\begin{array}{l}\text { 1. ROA } \\
\text { 2. BOPO }\end{array}$ & $45,8 \%$ & 3053 & 100 & $5 \%$ & 5 & Sehat \\
$\begin{array}{l}\text { Likuiditas } \\
\text { 1. Cash Ratio }\end{array}$ & $74,40 \%$ & 320 & 100 & $5 \%$ & 5 & Sehat \\
$\begin{array}{l}\text { 2. LDR } \\
\text { Total Nilai }\end{array}$ & $47,95 \%$ & 479,5 & 100 & $5 \%$ & 5 & Sehat \\
\hline
\end{tabular}


Jurnal Dinamika Manajemen, 5 (1) 2014,12-30

Tabel 16. Kuantitatif Perhitungan Tingkat Kesehatan Bank Pada PD. BPR BKK Banjarharjo Tahun 2010

\begin{tabular}{|c|c|c|c|c|c|c|}
\hline Komponen & Rasio & NK & $\begin{array}{l}\text { NK } \\
\text { Max }\end{array}$ & Bobot & $\begin{array}{l}\text { Nilai } \\
\text { Akhir }\end{array}$ & Indikator \\
\hline \multicolumn{7}{|l|}{ Permodalan } \\
\hline Rasio CAR & $16,66 \%$ & 168 & 100 & $25 \%$ & 25 & Sehat \\
\hline \multicolumn{7}{|l|}{ Kualitas Aktiva Produktif } \\
\hline 1. Rasio KAP & $2,22 \%$ & 89 & 100 & $25 \%$ & 22,25 & Sehat \\
\hline 2. Rasi PPAP & $96,1 \%$ & 96,1 & 100 & $5 \%$ & 4,805 & Sehat \\
\hline \multicolumn{7}{|l|}{ Rentabilitas } \\
\hline 1. ROA & $45,8 \%$ & 3053 & 100 & $5 \%$ & 5 & Sehat \\
\hline 2. $\mathrm{BOPO}$ & $69,85 \%$ & 377 & 100 & $5 \%$ & 5 & Sehat \\
\hline \multicolumn{7}{|l|}{ Likuiditas } \\
\hline 1. Cash Ratio & $64,59 \%$ & 645,9 & 100 & $5 \%$ & 5 & Sehat \\
\hline 2. LDR & $49,18 \%$ & 263,28 & 100 & $5 \%$ & 5 & Sehat \\
\hline Total Nilai & & & & & 72,055 & $\begin{array}{l}\text { Cukup } \\
\text { Sehat }\end{array}$ \\
\hline
\end{tabular}

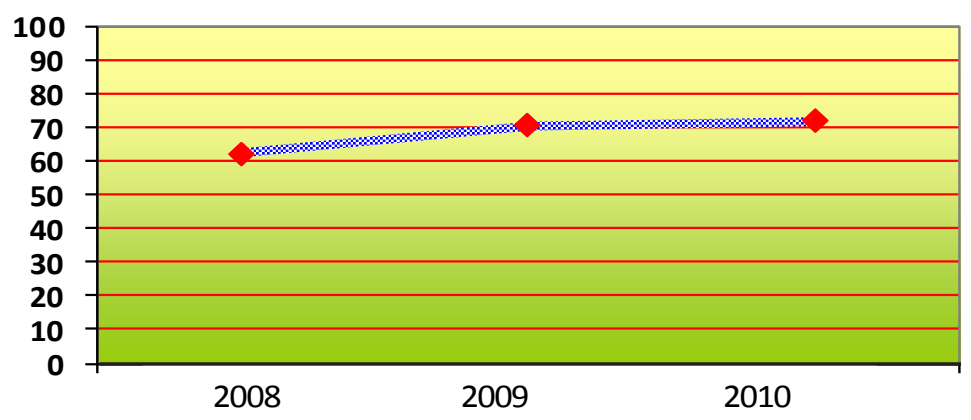

Grafik 1. Perkembangan Tingkat Kesehatan PD. BPR BKK Banjarharjo

Berdasarkan hasil penilaian kuantitatif, maka perkembangan tingkat kesehatan PD. BPR BKK BanjarharjoTahun 2008-2010 dapat dilihat pada Grafik 1. Pada Grafik 1 dapat dilihat bahwa tingkat kesehatan bank pada PD.BPR BKK Banjarharjopada tahun 2008 memiliki bobot nilai sebesar $62,5 \%$ yang berarti kurang sehat berdasarkan kriteria penggolongan tingkat kesehatan pada SK DIR BI No. 30/12/KEP/ DIR/97. Hal ini berarti kinerja pada PD. BPR BKK Banjarharjobelum cukup baik dan kegiatan operasional bank belumsesuai dengan prosedur yang berlaku.

Tingkat kesehatan bank padaPD. BPR BKK Banjarharjo pada tahun 2009 mengalami peningkatan dibandingkan dengan tahun 2008 dengan bobot nilai sebesar 70,75\% yang berar- ti bank dalam kondisi cukup sehat berdasarkan kriteria penggolongan tingkat kesehatan pada SK DIR BI No. 30/12/KEP/DIR/97. Hal ini berarti kinerja pada PD. BPR BKK Banjarharjosudah cukup baik dengan adanya peningkatan pada faktor likuiditas sehingga bank memiliki kemampuan dalam mengelola asset yang digunakan untuk membayar kewajiban yang harusdibayar pada waktunya dan kegiatan operasional bank telah sesuai dengan prosedur yang berlaku.

\section{SIMPULAN DAN SARAN}

Berdasarkan hasil penelitian dan pembahasan dapat disimpulkan bahwa, permodalan, Kualitas Aktiva Produktif (KAP), ROA, BOPO, Cash Ratio, Rasio LDR dan IRR pada 
Sri Murdiati \& Medi Tri Purwanto / Analisis Kinerja dengan Pendekatan ...

PD. BPR BKK Banjarharjotahun 2008-2010 termasuk dalam kriteria sehat. Kriteria sehat dalam permodalan artinya, bank mampu untuk mempertahankan pengelolaan terhadap modal sendiri dan aktiva-aktiva yang mengandung risiko, serta mampu untuk menutup kerugian atas kredit yang diberikan. Dalam KAP,artinya bank mampu untuk mempertahankan pengelolaan terhadap sejumlah aktiva tetap yang telah ditanamkan baik dalam kredit, surat berharga, penyertaan maupun penanaman dana lainnya dalam usaha untuk meningkatkan keuntungan serta mengurangi persentase kerugian yang terjadi.ROA pada PD. BPR BKK tahun 2008-2010 menunjukkan kriteria sehat karena biaya operasional yang ditanggung bank seimbang dengan pendapatan operasional yang diperoleh.BOPO juga mengalami peningkatan karena pendapatan operasional yang dihasilkan bank lebih besar daripada biaya operasional yang ditanggung oleh bank.

Cash Ratio padaPD. BPR BKK Banjarharjotahun 2008-2010 termasuk dalam kriteria sehat berarti bank memiliki kemampuan dalam mengelola asset yang digunakan untuk membayar kewajiban yang harus dibayar pada waktunya. Rasio LDR pada PD. BPR BKK Banjarharjomengalami kecenderungan peningkatan yang signifikan selama tahun 2008-2010 sehingga dana yang diterima oleh bank mengalami kenaikan baik dari tabungan, deposito berjangka, modal inti yang berarti kemampuan bank dalam menyalurkan kreditnya meningkat. IRR padaPD. BPR BKK Banjarharjo menunjukkan nilai yang positif. Semakin besar nilai interest risk ratio yang dicapai maka menunjukan arah yang positif dalam menghadapi resiko pasar.Perkembangan tingkat kesehatan pada PD. BPR BKK Banjarharjo tahun 2008-2010 untuk komponen Capital, Asset, Earning dan Liquidity cenderung mengalami peningkatan yangcukup signifikan.

Perbankan hendaknya meningkatkan manajemen pelaporankeuangannya dengan cara melaporkan semua data dan informasi keuangannya secara lengkap kepada BI. Di samping itu, laporan keuangan tersebut hendaknya juga disampaikan kepada masyarakat sebagai bentuk akuntabilitas perbankan kepada publik.Pihak BI hendaknya lebih meningkatkan manajemen pengadministrasian pelaporan keuangan dari masing-masing bank yang menjadi tanggung jawabnya. Pengadministrasian secara komputerisasi hendaknya terus ditingkatkan, baik dengan meningkatkan kualitas softwaredanhardware, maupun personalia pengelolanya. Selanjutnya, hendaknya dilakukan penelitian lanjutan yang sejenis dengan penelitian ini dengan cara memperluas sampel penelitian, data penelitian, maupun kedalaman analisisnya. Misalnya dengan menggunakan periode pengamatan yang lebihpanjang dan memasukkan aspek manajemen sebagai salah satu komponen dari CAMEL, sehingga memungkinkan akan diperoleh tingkat kesehatan bank yang lebih baik.

\section{DAFTAR PUSTAKA}

Anthony, R. N \&Govindarajan, V. 2005.Sistem Pengendalian Manajemen.Jakarta: Salemba Empat.

Arnold, B., Borio, C., Ellis, L \& Moshirian, F. 2012. Systemic Risk, Macroprudential Policy Frameworks, Monitoring Financial Systems And The Evolution Of Capital Adequacy. Journal of Banking \& Finance.36(12): 3125-3132.

Atikoğulları, M. 2009. An Analysis of the Northern Cyprus Banking Sector in The Post - 2001 Period Through the CAMEL Approach, International Research. Journal of Finance and Economics. 32: 212-229.

Baral, K. J. 2005. Health Check-up of Commercial Banks in the Framework of CAMEL: A Case Study of Joint Venture Banks in Nepal. The Journal of Nepalese Business Studies. 2(1): 41-55.

Derviz, A \& Podpiera, J. 2008. Predicting Bank CAMELS and S\&P Ratings: The Case of the Czech Republic. Emerging Markets Finance and Trade. 44(1): 117-130.

Gunsel, N. 2007. Financial Ratios and the Probabilistic Prediction of Bank Failure in North Cyprus. European Journal of Scientific Research. 18(2): 191-200.

Hansen, D.R\&Mowen, M. M.2004.Management Accounting.Jakarta:Salemba Empat.

Hays, F., De Lurgio, S. and A., Jr., Gilbert. 2009. Efficiency Ratios and Community Bank Perfor- 
mance. Journal of Finance and Accountancy. $1(1)$.

Mishra, A. K., Harsha, G. S., Anand, S \& Dhruva, N. R. 2012. Analyzing Soundness in Indian Banking: A CAMEL Approach. Research Journal of Management Sciences. 1(3).

Mulyono, T. P. 1995. Bank Budgeting Profit Planning Control Analisa Laporan Keuangan Untuk Perbankan. Edisi 1, Cetakan 1, 1996. Yogyakarta: BPFE.

Pilloff, S. J \& Rhoades, S. A. 2002. Structure and Profitability in Banking Markets. Review of Industrial Organization. 20: 81-98.

Ratnaputri, W. 2013. The Analysis of Islamic Bank Financial by Using Camel, Shariah Conformity and Profitability (SCnP). Jurnal Din- amika Manajemen. 4 (2).

Sarker, A. A. 2006. CAMELS Rating System in the Context of Islamic Banking: A Proposed 'S' for Shariah Framework. Journal of Islamic Economics Banking and Finance. 2(2): 212-229.

Shaw, M., Chang, J \& Chen, H.-J. 2013. Capital Adequacy And The Bank Lending Channel: Macroeconomic Implications. Journal of Macroeconomics. 36: 121-137.

Shehzad, C. T., de Haan, J \& Scholtens, B. 2010. The Impact Of Bank Ownership Concentration On Impaired Loans And Capital Adequacy. Journal of Banking \& Finance. 34(2): 399408.

Susilo, S. Y. 2000. Bank dan Lembaga Keungan lainnya. Jakarta: Salemba Empat. 